\title{
KONSTRUKSI REALITAS MELALUI PENDAYAGUNAAN KOSAKATA DALAM TAJUK RENCANA HARIAN KOMPAS
} \author{
Tajuk Rencana of Kompas Newspaper \\ Hermaliza ${ }^{1}$, Ermawati. S ${ }^{2}$, Alber ${ }^{3}$ \\ ${ }^{123}$ Universitas Islam Riau \\ hermaliza@uir.ac.id
}

Reality Construction Through The Use of Vocabulary in

\begin{abstract}
This Study focuses on the use of vocabulary in the daily editorial of Kompas. Ultilization of certain vocabulary by newspaper can form a reality or different views on a thing or event. Through this research, the writer tries to observe how the use of vocabulary in shaping the public's view or called the construction or reality, so that it is illustrated that vocabulary in a medium plays an important role in shaping the understanding of the audience or readers. The problem that is focused is "How is the contruction of reality through the use of vocabulary in the daily editorial of the Kompas?" The method used in this study is content analysis based on a critical discourse analysis approach, while the stages of data analysis include firstly the researcher will classify the data, then apply the theory of Roger Fowler et al by paying attention to the context of vocabulary usage, interpreting the data, finally making conclusions from the results found. By doing this research in the end the writer can describe the utilization of vocabulary that forms a certain reality. From the data found in this study, it can be concluded that the use of vocabulary in the daily editorial of the Kompas is based on constructing a positive reality and image to the government, many thing or events are describe classification vocabulary, which tend to benefit the government and marginalize other parties. So, it is clear that there is a practice of language in every sense.
\end{abstract}

Keywords: reality construction, vocabulary, the daily of Kompas

\section{PENDAHULUAN}

Kajian analisis wacana kritis (AWK) mengedepankan pemahaman terhadap wacana melalui pendekatan kritis. Fokus utama analisis wacana kritis adalah mengungkapkan bagaimana ketidakadilan pemberitaan terhadap pihak-pihak tertentu yang tidak dominasi dalam suatu kekuasan. Inti dari pendekatan kritis ini adalah memfokuskan pembahasan pada unsur kebahasaan yang menyiratkan makna ideologi tertentu. Titscher, Stefan dkk. (2000) analisis wacana kritis memandang wacana sebagai sebuah bentuk praktik sosial yang menyiratkan adanya hubungan peristiwa tertentu dengan situasi tertentu.

Fairclough dan Wodak (1989) dalam Darma (2014) menyebutkan pembahasan Analisis wacana kritis lebih menitikberatkan pada bagaimana seseorang atau sekelompok orang menyampaikan pendapatnya menggunakan bahasa, serta mengajukan pendapat masing-masing. Melalui pendapat tersebut, jelaslah bahwa agenda utama analisis wacana membongkar praktik-praktik ideologi dan kekuasaan pada media massa. Haryatmoko (2017) menyimpulkan beberapa tujuan kajian awk yaitu menelaah praktik wacana yang mengkonstruksikan masalah sosial, melihat bagaimana suatu ideologi dibekukan dengan bahasa, meningkatkan kesadaran agar peka terhadap ketidakadilan, diskriminatif, dan penyalahgunaan kekuasaan, serta menemukan solusi dalam berbagai hambatan dan mengahalangi perubahan sosial.

Penggunaan bahasa dalam media massa baik cetak maupun elektronik dalam pandangan kritis bukanlah hal yang tidak bermakna, karena setiap pemilihan bahasa merupakan suatu cara atau alat untuk 
meneguhkan argumen atau pendapat mereka. Sehingga dengan pemilihan bahasa tertentu mereka dapat memarjinalkan siapapun yang tidak memiliki kekuasaan atau atau dianggap tidak dominan dalam suatu pemberitaan. Peran media massa dalam pandangan kritis sampai pada tahap mampu mengontrol opini publik serta membentuk suatu realitas baru (Eriyanto, 2011). Oleh sebab itu, bahasa menjadi faktor penting untuk diamati untuk mengetahui praktik kekuasaan tersebut. Selain itu, Badara, (2012) analisis wacana yang bersifat kritis adalah pengkajian secara mendalam yang berusaha mengungkap kegiatan, sikap, serta penandaan berdasarkan bahasa yang digunakan. Pemahaman awk pun tidak terlepas dari peran konteks seperti yang disampaikan Djatmika (2014) dalam kajian wacana perlu diamati beberapa konsep diantaranya dengan melibatkan siapa yang menggunakan bahasa, bagaimana bahasa tersebut digunakan, mengapa menggunakannya dan kapan digunakan.

Dalam kajian analisis wacana bahasa menjadi sarana penting bagaimana suatu realitas dapat dipahami khalayak. Melalui bahasa seseorang dapat mengubahkan pikiran, mempengaruhi, bahkan mampu mengendalikan pikiran orang lain. Bahasa dapat menggambarkan suatu realitas menjadi penting atau sebaliknya untuk dibicarakan dan pihami bersama. Dalam penelitian ini, penulis memfokus kajian pada bagaimana suatu realitas terbentuk melalui penggunaan bahasa atau disebut konstruksi realitas. Rekonstruksi realitas tersebut diamati menggunakan pandangan Roger Fowler dkk yang menganggap setiap kosakata membawa makna tertentu dalam penggunaannya. Penggunaan kosakata yang berbeda untuk setiap peristiwa yang digambarkan dapat membentuk realitas baru bagi khalayak. Sebagaimana Hermaliza (2014) pada kajian sebelumnya menemukan bahwa penggunaan kosakata tertentu dalam sebuah wacana dapat menutupi pandangan publik terhadap hal yang sebenarnya terjadi sehingga banyak fakta tidak mampu dilihat jelas oleh pembaca.

Pendekatan analisis wacana yang diajukan Fowler dkk tersebut menganggap penggunaan bahasa berpengaruh besar terhadap konstruksi realitas, bahkan bahasa tidak saja mampu mencerminkan realitas, melainkan juga dapat menciptakan realitas. Berdasarkan pandangan tersebut, penulis tertarik mengkaji secara mendalam bagaimana suatu realitas yang ada dideskripsikan serta apa saja realitasrealitas yang terbentuk melalui pendayagunaan kosakata dalam media massa cetak terkhusus pada tajuk rencana harian Kompas. Dalam kajian ini yang menjadi permasalahan pokok adalah bagaaimana konstruksi realitas melalui pendayagunaan kosakata dalam tajuk rencana harian Kompas.

Beberapa penelitian yang berkaitan dengan penelitian yang akan dilakukan: Pertama, penelitian yang telah dilakukan oleh Dina Ramadhanti, pada Jurnal Gramatika Volume I, iI 2016 (89-99) dengan judul "Strategi Penggunaan kosakata dan tata bahasa dalam berita harian umum independen Singgalang" di STKIP PGRI Sumatera Barat. Masalah penelitian adalah bagaimanakah strategi penggunaan kosakata dan tata bahasa dalam berita harian umum independen Singgalang? Teori yang digunakan adalah analisis wacana kritis Roger Fowler (dalam Eriyanto 2000).

Hasil penelitiannya adalah berita pembunuhan dalam harian umum independen Singgalang pada umumnya lebih memihak kepada pelaku. Berita yang disajikan lebih mengarah kepada kondisi pelaku dan pembelaan-pembelaan sedangkan korban dimarginalkan seolaholah korban sebagai pemicu terjadinya pembunuhan. Kedua, penelitian yang telah dilakukan oleh Dadang S. Ansori, pada jurnal@rtikulasi Volume 10 Nomor 22011 dengan judul "Terorisme dalam pemberitaan majalah Tempo: analisis 
wacana Roger Fowler" di Universitas Pendidikan Indonesia. Berdasarkan hasil analisis data apat diungkap majalah tempo menggunakan beragam kosakata untuk memberikan atribut terorisme yang smeuanya bermakna pejoratif. Penggunaan kalimata aktif-transitif atributif mendominasi memungkinkan subjek dan objek peristiwa disampaikan secara terang dan terbuka.

Analisis wacana sebagai atau dikenal dengan singkatan (AWK) merupakan disiplin ilmu dengan pendekatan kritis. Istilah analisis wacana ini muncul sebagai dasar untuk memperoleh gambaran bahasa yang lebih komplek karena terdapat unsurunsur bahasa yang tidak cukup apabila dianalisis dengan menggunakan aspek struktur dan maknanya saja. Oleh karena itu, melalui analisis wacana dapat diperoleh penjelasan dan gambaran mengenai hubungan antara apa yang diujarkan, dengan apa yang dimaksudkan dan apa yang dipahami dalam konteks tertentu.

Dalam kajian Analisis wacana Kritis (AWK) bahasa diamati dan dianalisis dengan pendekatan kritis. Mengamati pemakaian bahasa yang dihubungkan konteks pemakaiannya, serta muatan unsurunsur lain dalam penggunaan bahasa dalam penyampaian informasi kepada khalayak. Terkait hal tersebut, Halliday (1978) berpendapat suatu wacana biasanya bersifat terikat konteks sehingga untuk menafsirkan makna suatu bahasa harus selalu mengaitkan dengan konteks wacana. Pandangan tersebut menegaskan untuk memahami sebuah wacana baik lisan maupun tulisan, tidak dapat dipisahkan dari konteksnya. Untuk menemukan "realitas" dalam suatu wacana maka harus dilakukan penelahaan terhadapa hal-hal yang melatarbelakangi wacana tersebut. Jelas dapat diketahui bahwa, analisis wacana kritis fokus pada pemakaian bahasa tutur dan tulisan sebagai praktik sosial. Dalam AWK suatu peristiwa selalu ditafsirkan dengan realitas-realitas yang ada bagaimana dinarasikan ke publik.

\section{Pendekatan Analisis Wacana yang memfokuskan pada Kosakata dan Tata Bahasa}

Pendekatan analisis wacana ini dipelopori Fowler dkk. dalam pandangannya untuk memahami struktur dan fungsi bahasa dalam suatu proses komunikasi adalah dengan cara memfokuskan perhatian pada tata bahasa dan kosakata serta praktik pemakaiannya, dengan demikian dapat diketahui praktik ideologi-ideologi tententu yang diselipkan melalui penggunaan kosakata dalam suatu pemberitaan.

Bahasa dilihat oleh Roger Fowler dkk. sebagai sistem klasifikasi. Maksudnya, bahasa dapat mendeskripsikan suatu keadaan atau peristiwa diceritakan. Teori ini memfokuskan pada bagaimana suatu peristiwa atau kejadian yang sama dapat dibahasakan dengan bahasa yang berbeda di media massa. Misalnya, perkosaan dapat dikatakan sebagai memperkosa, meniduri, menggagahi, memperawani, dan sebagainya. Menurut pandangan ini, perbedaan penggunaan kosakata untuk suatu peristiwa bukanlah suatu hal biasa saja, tetapi selalu membawa makna tertentu serta dapat membangun suatu realitas.

\section{Kosakata Membuat Klasifikasi}

Pada jenis kosakata pertama ini, diamati proses klasifikasi kosakata yang secara alamiah terjadi pada bahasa itu sendiri. Klasifikasi ini terjadi karena publik mempunyai pandangan yang berbeda terhadap suatu hal, mungkin saja dilatarbelakangi pengalaman dan kebiasaan berpikir tertentu. Kosakata yang bersifat klasifikasi memberi peluang kepada setiap penulis berita mengontrol informasi yang disampaikan kepada publik. Kosakata ini mampu mengarahkan pandangan khalayak dalam memahami suatu realitas.

\section{Kosakata Membatasi Pandangan}

Fowler dkk, menegaskan bahwa bahasa pada dasarnya bersifat membatasi, pembaca diajak untuk berpikir untuk memahami seperti itu, bukan yang lainnya. 
Artinya kosakata sangat menentukan bagaimana seseorang dapat memahami serta memaknai suatu peristiwa. Penyebabnya kerena publik tidak mengikuti dan melihat suatu peristiwa secara langsung. Itulah mengapa suatu kosakata memiliki kekuatan untuk merekonstruksi realitas. Contoh penggunaan kosakata membatasi pandangan dapat diamati dalam tabel di bawah ini:

\section{Kosakata Pertarungan Wacana}

Pertarungan wacana merupakan sifat dalam penggunaan bahasa, karena setiap orang berbicara dan menulis serta berpikir dengan caranya masing-masing. Jika dihubungkan dengan media massa maka setiap media memiliki versi atau pendapat masing-masing dalam menyikapi setiap peristiwa atau permasalahan. Artinya mereka selalu berusaha menyakinkan pembaca atas versinya dianggap benar dan dijadikan dasar dalam memahami suatu pemberitaan serta berpengaruh dalam pembentukan opini publik. Contohnya dikutip dari Eriyanto dalam kasus Aceh bagaimana perbedaan argumen terjadi dalam melalui kosakata. Dalam kasus tersebut ada dua pihak yaitu TNI dan GAM yang setiap mereka memiliki pandangan yang berbeda dalam konflik tersebut.

\section{Kosakata Marjinalisasi}

Pendapat utama dari Fowler dkk yaitu pilihan kata yang membentuk suatu rangkaian pernyataan tersirat nilai-nilai ideologis tertentu. Setiap kata selalu memiliki implikasi tertentu. Itulah mengapa menurut Fowler dkk bahasa selalu dianggap sesuatu yang tidak netral, dapat diarahkan sesuatu keperluan penggunanya. Melalui pemilihan kosakata tertentu terlihat bagaimana seorang aktor diceritakan dan digambarkan dalam suatu pemberitaan. Penggambaran inilah yang pada akhirnya akan memarjinalkan seseorang atau sekelompok dalam suatu pemberitaan.

\section{METODE PENELITIAN}

Untuk keperluan menganalisis data diperlukan suatu metode yang tepat, relevan dengan kajian ini peneliti menggunakan metode analisis isi. Analisis isi ini diterapkan karena penelitian yang dilaksanakan tidak hanya mendeskripsikan data sesuai kenyataan yang ada atau temuan saja, akan mengaitkan dengan konteks pemakaian bahasanya.

Penerapan metode ini akan mendeskripsikan bagaimana suatu kosakata didayagunakan untuk menciptakan realitas tertentu dengan memasukkan ideologi di dalamnya. Tahapan analisis data di antaranya pertama peneliti akan mengklasifikasi data ke dalam tabel, selanjutnya menerapkan teori Roger Fowler dkk dengan memperhatikan konteks pemakaian kosakata, menginterpretasi data, terakhir membuat kesimpulan dari hasil yang ditemukan

Sumber utama penelitian ini adalah sejumlah tajuk rencana harian Kompas, baik yang berisi pembahasan politik, sosial, ekonomi, hukum, agama dll. Untuk mengumpulkan data dengan menerapkan analisis isi secara kritis, peneliti mengamati dan menandai sejumlah kosakata yang menggambarkan suatu peristiwa yang dapat membentuk realitas tertentu.

Untuk menentukan sampel penelitian dilakukan dengan cara purvosive sampling (sampel bersyarat) maksudnya mengambil data dengan berbagai pertimbangan sesuai dengan fokus penelitian. Sampel dalam penelitian ini adalah tajuk rencana harian Kompas. Tajuk rencana tersebut peneliti tandai kosakatanya dengan tujuan menemukan pemakaian kosakata pembentuk klasifikasi, pembatas pandangan, pemicu pertentangan dan pembentuk marginalisasi. 


\section{HASIL}

Secara keseluruhan hasil penelitian menunjukkan beberapa kosakata yang turut didayagunakan dalam tajuk rencana harian Kompas, seperti yang dapat dilihat secara lebih jelas dalam bagian pembahasan berikut.

\section{PEMBAHASAN}

Dalam penelitian ini penulis menganalisis kosakata merujuk pada pendapat Fowler, dkk (dalam Erianto, 2000:134).

\section{Kosakata Pembentuk Klasifikasi}

Dari beberapa data yang ditemukan berikut dijelaskan terkait dengan kosakata pembentuk klasifikasi yaitu pada tajuk rencana dengan judul "Bendung Dampak Ekonomi Korona"

(01) Kepanikan, baik oleh pemerintah, pelaku usaha, maupun masyarakat, jelas tak akan menolong. Masyarakat tampaknya masih cemas, dua kasus terkonfirmasi ini baru puncak gunung es, mengingat posisi Indonesia dikepung sejumlah Negara yang sudah lebih dulu terpapar, adanya kesan pemerintah terlalu menggampangkan selama ini, dan juga mengingat bukan hal mudah mengamankan 135 pintu masuk yang ada. (Rabu, 4 Maret 2020)

Kutipan (01) termasuk kosakata pembentuk klasifikasi dengan mendayagunakan kosakata dikepung dan pemerintah terlalu menggampangkan. Pertama, dilihat penggunaan kata dikepung, kata itu dapat dipadankan dengan dikelilingi, hanya saja penggunaan kata dikepung maknanya lebih spesifik dan menjurus. Sesuai kutipan tersebut "mengingat posisi Indonesia dikepung sejumlah negara yang sudah lebih dulu terpapar". Artinya, mau tidak mau rakyat atau masyarakat Indonesia pasti akan terkena/ terjangkit virus korona karena Indonesia dikelilingi oleh negara lain yang sudah terpapar virus tersebut, sehingga tidak akan bisa lolos begitu saja. Lebih lanjut, Harian Kompas sangat jelas menyatakan dan memberikan pemahaman kepada publik bahwa "adanya kesan pemerintah terlalu menggampangkan selama ini”. Kata menggampangkan dapat dipadankan dengan memudahkan dan membuat menjadi mudah, menganggap enteng (remeh, sepele). Jelas, hal itu akan sangat merugikan masyarakat, tidak hanya sekadar rugi ekonomi tetapi bisa lebih besar dari itu jika pemerintah tidak cepat tanggap. Secara tidak langsung pendayagunaan kosakata itu berdampak negatif pada kinerja pemerintah yang terlihat lambat dan terlalu meremehkan penanganan masalah korona ini. Selanjutnya pada tajuk dengan judul yang sama terdapat beberapa penggunana kosakata yang tergolong membentuk klasifikasi.

(02) Kredibilitas langkah pemerintah menjadi penting di sini. Masyarakat tidak cukup hanya diyakinkan dengan narasi bagaimana pemerintah sudah siap merespon. Kesiapan dan kesiagaan nyata di lapangan, terutama dalam langkah preventif, jauh lebih penting. Dalam beberapa kasus, komentar pejabat terkait yang terkesan blunder, tidak hanya menawarkan keamanan semu, tetapi justru bisa meningkatkan ketakpercayaan pada kesiapan kita mencegah penyebaran virus. (Rabu 4 Maret 2020)

Pendayagunaan kosakata pembentuk klasifikasi dalam kutipan (02) juga disampaikan secara langsung oleh harian Kompas dalam bentuk kritikan terhadap pemerintah dan pejabatnya. Hal itu tergambar pada bagian kutipan "masyarakat tidak cukup hanya diyakinkan dengan narasi" bahwa masyarakat memerlukan ketegasan dan kesiapan yang nyata dari pemerintah bukan hanya sekadar cerita kosong yang disampaikan kepada publik. Tentunya, melalui penggunaan kosakata tersebut terbentuklah suatu realitas bahwa penanganan virus korona oleh pemerintah 
belum maksimal serta tidak adanya tindakan jelas dirasakan masyarakat.

Selanjutnya, pendayagunaan kosakata yang terkesan blunder jelas sekali ditujukan kepada pejabat yang berkomentar tetapi dinilai keluar dari jalurnya. Hal itu dipertegas lagi dengan penggunaan kosakata keamanan semu, yang menyiratkan makna bahwa pejabat terkait yang menangani kasus tersebut terkesan menawarkan keamanan kepada publik walaupun sebenarnya tidak dapat diwujudkannya. Jelas, hal itu makin memperburuk citra dan pandangan negatif dari khalayak/ publik terhadap pemerintah dan pejabat terkait. Penggunaan kosakata pembentuk klasifikasi dapat pula diamati pada tajuk berjudul "Bangun Kredibilitas KPU”.

(03) Ketika bangsa ini luar biasa heboh mengatasi wabah virus korona, Komisi Pemilihan Umum malah menebar kehebohan lain. Kembali komisioner KPU diberhentikan. (Kompas, Jumat, 20 Maret 2020)

Kutipan (03) termasuk kosakata pembentuk klasifikasi dengan menggunakan kosakata menebar, penggunaan kata itu disempurnakan dengan kata lainnya yang berada disebelahnya yakni kehebohan lain. Kompas ingin memperlihatkan kepada publik/ khalayak bahwa komisioner KPU telah membuat kegaduhan ataupun keributan lain pada saat bangsa sedang mengatasi wabah virus korona. Selain itu, bentuk penegasan atas kejadian itu juga dapat dilihat pada bagian akhir kalimat yang berbunyi 'Kembali komisioner KPU diberhentikan' agar publik atau masyarakat bisa mengetahui sendiri bagaimana kinerja dari pejabat KPU yang kembali diberhentikan menyusul pejabat sebelumnya yang juga diberhentikan. Dengan Penggunaan kosakata tersebut tentu membentuk realitas pandangan yang negatif terhadap pejabat/ petinggi KPU. Konstruksi realitas yang tampak dari wacana terkait "Bangun Kredibilitas KPU" dari sejumlah peristiwa yang dismpaikan Kompas aktor diwacana tersebut digambarkan dengan citra negatif, maka realitas yang akan diterima publik adalah bahwa KPU perlu meningkatkan kinerjanya, hal ini dapat pula diamati pembaca dari penggunaan kosakata pada bagian judul, yang memberikan klasifikasi realitas ke publik tentang kinerja KPU. Pada Tajuk yang sama juga tampak gambaran penegasan peristiwa atau hal yang sama.

(04) Selain memberikan sanksi kepada Evi, DKPP juga memberikan peringatan keras terakhir kepada ketua KPU dan keempat anggota KPU tersisa terkait pelanggaran kode etik tersebut. (Kompas, Jumat, 20 Maret 2020)

Kutipan (04) memperjelas tentang sanksi yang diberikan kepada Evi oleh DKPP. Penekanan terlihat jelas juga dalam penggunaan kata-kata peringatan keras terakhir yang bermakna itu merupakan teguran yang sangat tegas dan final diberikan oleh DKPP kepada petinggi KPU dan anggotanya. Selain itu, Kompas secara jelas dan tegas menyampaikan bahwa peringatan atau teguran itu tidak hanya ditujukan kepada ketua KPU saja tetapi juga kepada keempat anggota KPU lainnya, dengan menggunakan kosakata tersisa. Pendayagunaan kosakata tersebut dimaksudkan untuk membangun dan membentuk pandangan publik bahwa itulah jumlah staf KPU yang masih aktif bekerja.

(05) Putusan DKPP ini tentu kian merontokkan kepercayaan publik kepada KPU. Belum lama berselang, 16 Januari 2020, DKPP juga memberhentikan tetap Wahyu Setiawan setelah ditangkap Komisi Pemberntasan Korupsi (KPK) dalam kasus suap. Berarti, sudah dua dari tujuh komisioner KPU periode 2017-2022 yang diberhentikan DKPP pada tahun ini. (Jumat, 20 Maret 2020)

Kutipan (05) khususnya kosakata merontokkan kepercayaan publik pada kalimat pertama langsung ditujukan kepada KPU. Dijelaskan bahwa keputusan yang ditetapkan oleh DKPP makin menurunkan, meruntuhkan bahkan bisa jadi menghilangkan harapan dan keyakinan 
publik terhadap kinerja KPU. Penggunaan kata merontokkan tentu punya maksud tersendiri bagi penulisnya. Dalam hal ini, Kompas berusaha menunjukkan realitas kepada khalayak tentang keberadaan KPU yang sebenarnya. Tidak selesai dengan kalimat pertama, secara jelas dan gamblang dipertegas lagi pada kalimat berikutnya tentang pemberhentian komisioner KPU yang tertangkap terkait kasus suap.

(06) Kini, tugas berat dari komisioner yang tersisa di bawah kepemimpinan Ketua KPU Arief Budiman untuk mencegah agar pelanggaran tidak lagi terjadi, menular, apalagi mewabah. Kredibilitas KPU tidak boleh rontok. (Kompas, 20 Maret 2020)

Sebagaimana terlihat pada kutipan (06) dijelaskan bahwa KPU mempunyai tugas yang berat di bawah kepemimpinan Ketua KPU Aref Budiman. Realitas yang coba ditunjukkan Kompas kepada publik sangat jelas dengan penekanan kosakata menular dan mewabah. Kata menular dapat dipadankan dengan mengenai yang lain, menjangkit atau memengaruhi yang lainnya, sedangkan kata mewabah maknanya lebih parah karena sudah menjadi wabah. Sebenarnya, itu secara tidak langsung menjadi teguran keras bagi komisioner KPU serta realitas tentang harapan besar yang diberikan kepada komioner atau ketua yang baru agar hal serupa tidak terulang lagi berikutnya. Tampak jelas pada akhir kalimat ditegaskan bahwa Kredibilitas KPU tidak boleh rontok. Maknanya, jangan sampai kepercayaan publik kepada KPU hilang selamanya. Penggunaan kosakata pembentuk klasifikasi berikutnya yaitu pada wacana "Bersama atasi Covid-19"

\section{Kosakata Membatasi Pandangan}

Penggunaan kosakata membatasi pandangan tampak pada wacana berjudul "Bendung dampak Ekonomi Korona" yaitu:

(07) Pemerintah dan berbagai komponen bangsa lainnya perlu diingatkan untuk bahu-membahu mengatasi dampak wabah yang belum bisa diperkirakan sampai kapan. Sebagai akibat korona, Dana Moneter Internasional (IMF) pun merevisi ke bawah pertumbuhan global yang sebelumnya sudah terdampak perang dagang AS-China. Sejumlah Negara yang ekonominya terancam kontraksi atau resesi akibat dampak korona dipaksa melakukan hal yang sama. (Kompas, Rabu, 4 Maret 2020)

Kosakata yang bercetak miring pada pendangan yang membatasi pandangan publik tentang kinerja pemerintah dan komponen lainnya dalam penanganan kasus korona yang coba diingatkan kembali oleh harian Kompas. Penggunaan kosakata bahumembahu bermakna tolong menolong, gotong royong, atau bersama-sama membenahi suatu permasalahan. Penggunaan kosakata tersebut menciptakan realitas bahwa setiap komponen bangsa harus bekerjasama dalam menghadapi wabah korona ini, pemerintah membuat kebijakan-kebijakan untuk penanganan wabah korona serta kebijakan yang berkaitan dengan perekonomian rakyat tentu perlu dukungan masyarakat dalam bentuk pematuhan terhadap aturan atau kebijakan yang telah diputuskan tersebut. Begitu juga dengan penggunaan kosakata perang dagang yang membatasi pandangan publik tentang pertumbuhan ekonomi Global.

(08) Rencana pemerintah meluncurkan berbagai stimulus dan membenahi iklim investasi dapat tantangan baru. Ujian berat bagi ekonomi Indonesia, yang beberapa tahun terakhir berusaha memacu investasi dan pertumbuhan untuk keluar dari perangkap pendapatan menengah. Perang dagang, kasus gagal bayar asuransi dan kini covid-19.... (Kompas, Rabu, 4 Maret 2020)

Kosakata yang bercetak miring pada kutipan (08) menandakan kosakata pembatas pandangan yang membatasi pandangan publik tentang rencana pemerintah. Penggunaan kosakata membenahi iklim investasi pada dasarnya sama maknanya dengan mengurus keadaan 
investasi. Dalam kutipan tersebut, harian Kompas memberikan penekanan bahwa rencana pemerintah mendapatkan tantangan baru terkait dengan usaha untuk mengurus keadaan investasi. Dengan adanya penggunaan kosakata tersebut, terbentuklah suatu realitas bahwa pemerintah sudah melakukan berbagai usaha dalam membenahi kondisi ekonomi di Indonesia, dalam hal ini pemerintah sebagai aktor yang digambarkan mendapat citraan positif, sehingga konstruksi makna yang tercipta membatasi pandangan publik terhadap berbagai kelemahan kinerja pemerintah dalam menangani korona. Selanjutnya kosakata membatasi pandangan terdapat pada wacana "Menjaga Kepercayaan Masyarakat"

(09) Untuk membantu dunia usaha, pemerintah melonggarkan pajak penghasilan karyawan, pajak impor untuk sector usaha tertentu, hingga mempercepat restitusi pajak. Pemerintah juga berencana menaikkan defisit Anggaran Pendapatan dan Belanja Negara (APBN) menjadi 2,5 persen dari asumsi semula 1,76 persen. (Kamis, 19 Maret 2020)

Penggunaan kosakata melonggarkan pada kutipan tersebut tergolong membatasi pandangan. Pada dasarnya kosakata melonggarkan secara tidak langsung dapat menciptakan atau membangun realitas bahwa pemerintah telah membantu masyarakat dalam pembayaran pajak. Padahal sebenarnya setelah dipahami konteks wacananya, kata menlonggarkan maknanya hanya memberi jeda waktu ataupun kemudahan administrasi, tetapi pajak tetap harus dibayarkan. Penggunaan kosakata melonggarkan dalam konteks wacana ini mengarah kepada makna meringankan yang artinya mengurangi beban pajak yang harus dibayarkan.

\section{Kosakata Pertarungan Wacana}

Berikut dijelaskan data terkait pendayagunaan kosakata pertarungan wacana pada data.

\begin{tabular}{|c|c|c|}
\hline Peristiwa & $\begin{array}{c}\text { Versi } \\
\text { Pemerintah }\end{array}$ & $\begin{array}{c}\text { Versi Harian } \\
\text { Kompas }\end{array}$ \\
\hline $\begin{array}{l}\text { Dampak } \\
\text { Ekonomi } \\
\text { Korona }\end{array}$ & $\begin{array}{l}\text { Kita } \\
\text { berkepentingan } \\
\text { jangan sampai } \\
\text { terjadi efek } \\
\text { bola salju, } \\
\text { terutama dari } \\
\text { sisi dampak } \\
\text { ekonomi, pasca } \\
\text { informasi ini. }\end{array}$ & $\begin{array}{l}\text { Menyelamatkan } \\
\text { ekonomi dari } \\
\text { dampak korona, } \\
\text { lewat berbagai } \\
\text { stimulus, } \\
\text { memang sangat } \\
\text { penting. Namun, } \\
\text { mencegah } \\
\text { penyebaran } \\
\text { virus } \\
\text { menjaga dan } \\
\text { keselamatan } \\
\text { warga jauh lebih } \\
\text { penting. }\end{array}$ \\
\hline
\end{tabular}

Usaha untuk membendung dampak ekonomi korona, terjadi perbedaan pendapat antara pemerintah dan harian Kompas. Pihak pemerintah berdalih dengan mengatakan Kita berkepentingan jangan sampai terjadi efek bola salju, terutama dari sisi dampak ekonomi, pasca informasi ini. Pernyataan itu menyiratkan bahwa pemerintah mempunyai kepentingan, sementara harian Kompas menegaskan bahwa menyelematkan ekonomi dari dampak korona, lewat berbagai stimulus, memang sangat penting. Namun, mencegah penyebaran virus dan menjaga keselamatan warga jauh lebih penting.

\section{Kosakata Marginalisasi}

Penggunaan kosakata pembentuk Marginalisasi tampak dalam wacana berjudul "Benahi Total Layanan Publik" yaitu

(10) Bangsa ini belum jauh berlari membenahi pelayanan Publik, penundaan berlarut hingga penyalahgunaan prosedur terus terjadi, bahkan mendominasi. (Kamis, 5 Maret 2020)

Pendayagunaan kosakata pembentuk marginalisasi berupa kritikan tentang layanan publik pada kosakata penundaan berlarut dan penyalahgunaan prosedur, penggunaan kosakata tersebut menciptakan realitas banyaknya aduan masyarakat terkait 
pelayanan umum yang tertunda dalam berbagai bidang. Misalnya kepegawaian, ketenagakerjaan, administrasi kependudukan, kepolisian, dan agraria/ pertanahan. Kritik tersebut jelas merugikan pemerintah karena memberikan citraan negatif dan memarginalkan pemerintah dalam suatu kasus yang terjadi sehingga menciptakan gambaran umum kinerja pemerintah secara keseluruhan.

\section{IMPLIKASI}

Dari sejumlah data yang ditemukan dapat disimpulkan bahwa pendayagunaan kosakata dalam Harian Kompas pada dasar mengontruksi realitas dan citra positif kepada pemerintah, banyak hal atau peristiwa yang digambarkan dengan kosakata klasifikasi, yang cenderung menguntungkan pemerintah dan memarginalkan pihak yang lain. Jadi, jelas adanya praktik bahasa dalam setiap makna. Selain. Kompas lebih berhati-hati dalam pemilihan kosakata dalam menyikapi berbagai peristiwa, cenderung menggunakan kosakata yang sifatnya netral dan isi tajuk lebih fokus pada memberikan informasi.

\section{REFERENSI}

Badara. Aris. (2012). Analisis Wacana: Teori, Metode, dan penerapannya pada Wacana Media. Jakarta: Kencana.

Darma. Yoce Aliah. (2014). Analisis Wacana Kritis. Bandung: Refika Aditama.

Djatmika. (2014). Pernik Kajian Wacana. Yogyakarta: Graha Ilmu.

Eriyanto. (2001). Analisis Wacana: Pengantar Analisis Teks Media. Yogyakarta: LKS Yogyakarta.

Haryatmoko. (2017). Critical Discourse Analysis. Jakarta: Rajawali Pers.

Hermaliza. (2014). Pendayagunaan Kosakata dalam Wacana kritik Politik Editorial Koran Tempo: Analisis
Wacana Kritis. GERAM (Gerakan Aktif Menulis), 4(1), 10-20.

Ramadhanti. Dina. (2016). Strategi penggunaan Kosakata dan Tata Bahasa dalam berita harian umum Independen Singgalang. Gramatika, 1(2).

https://doi.org/https://dx.doi.org/10.22 202/jg.2015.v1i1.1160

Titscher. Stefan dkk. (2000). Metode Analisis Teks dan Wacana. Yogyakarta: Pustaka Pelajar. 